УДК 369.032

DOI: https://doi.org/10.26642/jen-2020-1(91)-43-47

Д.П. Мельничук, д.е.н., доц. І.А. Войналович, к.е.н. I.М. Леган, к.е.н.

T.М. Тростенюк, аспірант

Державний університет «Житомирська політехніка»

\title{
Збереження людського капіталу як пріоритет функціонування системи соціального захисту та соціального забезпечення у добу глобальних економічних трансформацій
}

\begin{abstract}
Статтю присвячено актуальним проблемам розвитку системи соиіального захисту та сочіального забезпечення у контексті збереження людського капіталу України. Аргументовано, щзо система соиіального захисту та соиіального забезпечення, серед іншого, відіграє надважливу роль у процесі збереження людського капіталу иляхом підтримки економічно активного населення за скрутних життєвих обставин, щзо не обмежуються втратою робочого місия, а й екстраполюються у площину життєзабезпечення тих категорій громадян, які з різних причин не мають можливості брати участь у процесі суспільного виробництва, задовольняючи тим самим свої потреби самостійно. Проаналізовано особливості вітчизняної системи соціального захисту й соціального забезпечення. Виходячи з тих позицій, щзо людський капітал є прогресивним імперативом суспільного розвитку у добу постіндустріальних перетворень, доведено високу значущість системи сочіального захисту та сочіального забезпечення, яка, зокрема має ставити за мету попередження декваліфікації працівників, знецінення їх професійних знань та навичок, зменшення тягаря надмірного демоекономічного навантаження. Наведено аргументи щзодо того, щзо глобалізація світового господарства перешкоджає реалізаиії ефективних стратегій стосовно модернізації системи соиіально-економічних відносин на територіях країн, які не є лідерами геополітики, негативно позначаючись на якості життя населення та перспективах суспільного розвитку. Запропоновано заходи щзодо удосконалення системи соціального захисту та сочіального забезпечення як передумови поліпшення якості й підвищення рівня життя населення у добу прогресуючих тенденцій глобалізаційного змісту, за яких підходи щуодо вирішення багатьох завдань сочіально-економічного розвитку потребують кардинально інших за характером управлінських рішень на всіх рівнях державного управління.

Ключові слова: соціальне забезпечення; соціальний захист; державне управління; людський капітал; глобалізація економіки; соціально-трудова сфера; соиіальна відповідальність; якість життя.
\end{abstract}

Постановка проблеми. Віднедавна глобалізаційна проблематика набула високої актуальності, що пояснюється посиленням впливу транснаціональних зрушень на економіку, культуру, соціально-трудову сферу країн світового співтовариства. 3 наслідками глобалізації зіштовхуються як розвинуті держави, так i ті, що розвиваються. Втім, загрози та виклики для різних країн принципово різні: тоді як широкий загал намагається протидіяти погіршенню соціально-економічної, санітарно-епідеміологічної та соціокультурної ситуації, розвинуті країни не безпідставно остерігаються, що останнє безпосередньо торкнеться і їх унаслідок інтенсифікації міграційних та логістичних процесів, оновлення принципів розподілу доходів через зміну структури світового господарства. Вони відчайдушно намагаються запобігти руйнівному для суспільного прогресу міжрасовому дисонансу, негативному перебігу подій у соціально-трудовій сфері, i, як наслідок, зниженню рівня та якості життя населення. Суттєвими для лідерів геополітики є виклики, пов'язані з перспективами подальшого ведення виробничої та збутової діяльності на територіях країн «другого» й «третього» світів, задіяння ресурсної бази останніх в інтересах власного розвитку інструментами транснаціоналізації бізнесу. Цілком закономірною є полярність суджень щодо природи та наслідків глобалізації, а також активності організацій, чия діяльність значною мірою визначає перспективи розвитку людства у добу глобальних економічних трансформацій.

Так під егідою ПРООН (United Nations Development Program), проблеми глобалізації та ії впливу на перебіг суспільно важливих процесів неодноразово порушувалися у доповідях про людський розвиток, зокрема: «Глобальні виміри людського розвитку» (1992р.), «Глобалізація з людським обличчям» (1999р.), «Міжнародне співробітництво на міждоріжжі: допомога, торгівля та безпека у світі нерівності» (2005 р.), «Що стоїть за нестачею води: влада, бідність та глобальна криза водних ресурсів» (2006 р.), «Забезпечення стійкого прогресу людства: зменшення вразливості та формування життєздатності» (2014 р.) тощо. У цих доповідях йдеться про загрози, зумовлені глобалізацією, при цьому акцент робиться на тому, що спричинені негаразди можуть бути нівельовані та відкориговані сумісними діями світової спільноти. Але 
наскільки щирими є позиції доповідачів? Наскільки глибокими й безкорисливими є занепокоєння розвинутих держав світу стосовно загроз, які несе глобалізація країнам, які розвиваються, тоді як саме лідери геополітичної гри й дали старт соціально-економічним трансформаціям у світових масштабах? «Спеціального розгляду потребує актуальне питання про політику так званих подвійних стандартів в умовах глобалізації, яка набуває різних форм прояву і найчастіше характеризує відносини між промислово розвинутими країнами та країнами, що розвиваються», - цілком правомірно зазначають українські вчені П.Леоненко та О.Черепніна [3, с. 294].

Серед іншого, важливе значення має проблема збереження людського капіталу за часів глобальних економічних трансформацій. Перебіг процесів у соціально-трудовій сфері України дає підстави стверджувати про декваліфікацію великих обсягів економічно активного населення, зниження мотивації до продуктивної суспільно корисної праці, втрату прогресивних трудових цінностей та професійної ідентичності внаслідок прогресуючих загрозливих тенденцій у сфері зайнятості, надмірної трудової міграції, низької ефективності функціонування внутрішнього ринку праці, що в цілому призводить до знецінення складових людського капіталу у загальнонаціональних масштабах.

Аналіз останніх досліджень та публікацій. Проблеми глобалізації світового господарства, їх взаємозв'язок 3 пріоритетами соціально-економічного розвитку проаналізовано у роботах таких дослідників, як: Б.Баді, Д.Данінг, П.Дракер, Р.Зевін, Л.Ніл, К.Омае, Л.Сінцеров, Т.Спайбі, С.Перегудов, П.Тернер, А.Уткін. Вплив глобалізації на систему соціально-трудових відносин, формування та використання людського капіталу, механізми державного управління у контексті вимоги підвищення ефективності соціального захисту та соціального забезпечення досліджено вітчизняними й зарубіжними вченими: О.Герасименко, О.Грішновою, А.Гриненком, В.Звонарем, С.Карпухіним, А.Колотом, Е.Лібановою, О.Макаровою, А.Ореховським, І.Парамоновою та іншими. Разом 3 тим, динамічна диверсифікація глобалізаційних процесів, посилення їх тиску на соціально-трудову сферу, вимагає подальших наукових пошуків та розроблення спрямованих на удосконалення практики соціального захисту й соціального забезпечення рекомендацій.

Метою дослідження $є$ уточнення ролі соціального захисту та соціального забезпечення у процесі збереження людського капіталу на всіх рівнях економічної системи, визначення переваг і недоліків вітчизняної системи соціального захисту й соціального забезпечення та конкретизація пріоритетів її розвитку.

Викладення основного матеріалу дослідження. Досліджуючи причини, загрози та наслідки глобалізаційних процесів, А.М. Колот та О.О. Герасименко зробили висновок, що в результаті останніх виграш у реальних доходах членів домогосподарств у період 1988-2008 рр. був найбільшим у тих, хто належав до 50-го акумульованого перцентиля глобального розподілу доходів і серед найбагатших. Найменший виграш мали члени домогосподарств, які перебували біля 80-го акумульованого перцентиля світового розподілу доходів, більшість з яких належала до нижнього прошарку середнього класу багатих країн світу. Тож, більше від інших виграли бідні та середній клас багатьох країн Азї̈, а програв «нижній середній клас багатого світу». «І це мало кого здивує, - зазначають вчені, - адже йдеться про те, що може бачити кожна неупереджена людина, спостерігаючи за змінами у країнах Заходу останніх двох десятиліть, натомість азійські країни (принаймні більшість із них) почали «підійматися з колін» [2, с. 108]. Разом 3 тим, у контексті порушеної у статті проблеми, доречним буде й інше питання: чому в результаті глобалізаційних зрушень пріоритет у розміщенні наукомістких виробництв свого часу був наданий країнам Азії, а не країнам з більш, на перший погляд, близькими ментальними цінностями: тим країнам, що стали на шлях ринкових перетворень, зокрема, Україні? Зрозуміло, є безліч аспектів геополітичного характеру. Втім, не лише вони визначили зміст рішень щодо розміщення капіталу лідерів геополітики. Можна стверджувати, що багато причин було пов'язано з якісними характеристиками працівників, які на той час не мали рис, що гарантували б ефективне використання іноземного капіталу. Серед них:

- недостатньо відповідальне ставлення до своїх обов'язків та до трудової діяльності в цілому;

- низький рівень завзятості та зацікавленості в процесі досягнення загальноорганізаційних цілей;

- категоричне небажання приймати на себе відповідальність за конкретні рішення та наслідки їх реалізації;

- недостатнє усвідомлення нових вимог до найманого працівника в умовах ринкової економіки, зокрема, ставлення до посадового окладу як до винагороди не за результати праці, а за перебування на робочому місці;

- завищені очікування щодо трудової винагороди, які часто не відповідали рівню кваліфікації працівника, іноваційності та результативності його праці;

- низький рівень регіональної мобільності економічно активного населення, що перешкоджало формуванню ефективно функціонуючого ринку праці та професійному розвитку працівників;

- надмірна соціальна активність на робочому місці, схильність до прямих або прихованих конфліктів 3 адміністрацією, низький рівень трудової дисципліни та дисципліни праці;

- неготовність перенавчатися, професійно адаптуватися, підвищувати конкурентоспроможність на ринку праці, прагнути до застосовування прогресивних професійних знань та навичок у формі людського капіталу. 
Такі характеристики більшою мірою нівельовано історичним поступом українського суспільства. Втім, вони, будучи одночасно і наслідком, і причиною затягування перехідних процесів, потребують подальших кардинальних змін, що в умовах наростання соціально-економічних диспропорцій є функцією не лише освітнього простору, а й системи соціального захисту та соціального забезпечення населення. Твердження обгрунтовується багатьма обставинами. Щодо економічно активних осіб, то система соціального захисту та соціального забезпечення має підтримати їх трудові цінності, прагнення, ініціативи, ентузіазм - чи має людина на сьогодні робоче місце, чи ні. Крім того, економічно активне населення не повинне бути відірваним від трудових процесів, переобтяженим піклуванням про осіб, що 3 різних причин втратили працездатність і перебувають на його утримані. Ці та інші фактори аргументують надважливу роль системи соціального захисту та соціального забезпечення населення у соціальноекономічному розвитку України. I цю роль важко переоцінити як з позицій загальнолюдських цінностей та пріоритетів суспільного розвитку, так і забезпечення передумов, необхідних для збереження людського капіталу за часів масштабних глобалізаційних змін.

Людським капіталом є економічний актив, що формується в результаті інвестицій шляхом набуття знань та доцільної видозміни продуктивних спроможностей індивіда (трудового колективу, суспільства), а також є формою представлення останніх під час трудової діяльності, яка забезпечує певний дохід учасникам інвестиційно-виробничого процесу [4, с. 137]. Відповідно, шлях до вирішення та й взагалі розуміння проблеми людського капіталу неминуче пролягає крізь усвідомлення важливості та необхідності оптимізації демографічних процесів, розвитку сучасної системи освіти та професійної підготовки, відновлення рекреаційного комплексу, розбудови якісної системи охорони здоров'я, створення ефективно функціонуючої системи соціального захисту та соціального забезпечення як важеля, призначенням якого є збереження людського капіталу за складних обставин, які неминуче настають у житті як окремої людини, так і суспільства в цілому. Натомість, як засвідчують результати дослідження, проблеми соціального захисту та соціального забезпечення були і залишаються в Україні гострими та нерозв’язаними, через що, найчастіше, складові людського капіталу українців перебувають під загрозою знецінення унаслідок дії різних чинників інституційного, ринкового, демографічного, політичного характеру. Складність розв'язання означених завдань визначається не лише комплексністю проблеми, а й iii зумовленістю глобальними, насамперед економічними, тенденціями, що прогресують у сучасному світі.

Глобалізація - складний та суперечливий процес. Показово, що західні вчені толерантніші, ніж їхні колеги 3 країн, що розвиваються, оцінюють його вплив на систему суспільних відносин. Так П.Дракер, характеризуючи тенденції у суспільному розвитку, робить акцент на закономірному формуванні нової системи цінностей сучасної людини та неминучій трансформації ідеї національної держави у бік глобальної економіки й глобального соціуму. Згідно з позицією вченого, сучасна епоха - це епоха радикальних змін в основах суспільного устрою, що супроводжуються трансформацією капіталістичного суспільства у суспільство, яке засноване на знаннях [10]. Такий підхід аргументує щільний зв'язок проблеми збереження людського капіталу з проблематикою удосконалення системи соціального захисту й соціального забезпечення, яка за певних умов має бути покликана сприяти збереженню знань, досвіду, професійних навичок та здоров'я економічно активного населення.

Більшість вчених висловлює суттєві занепокоєння 3 того приводу, що процес глобалізації безпосередньо впливає на функціонування національних економік та перешкоджає стійкому розвитку. У науковій літературі широко обговорюються три можливі шляхи суспільно-економічного розвитку у XXI столітті, а саме: подальший розвиток глобалізаційних процесів у їх сучасному форматі; антиглобалізація, прихильники якої вважають за необхідне жорстко обмежити міжнародні економічні відносини та повернути глобальний процес у межі національних економік; глобалізація й стійкий розвиток або так звана глобалізація з людським обличчям. Аналізуючи ці альтернативи, автори [8] доходять висновку, сподіватися на деякі 3 них недоречно. Перша - є глухим кутом, оскільки розширює гаму економічних, екологічних, соціальних суперечностей та породжує все нові конфлікти; друга - $€$ нереальною, оскільки повернути глобальний бізнес у національні межі неможливо: «... це приблизно таке ж завдання, як повернутися до феодальних відносин після завершення промислової революції». Тож єдиним прийнятним варіантом - i 3 цим важко не погодитися - вчені вважають такий соціальноекономічний розвиток, що передбачає поєднання глобалізаційних процесів зі стійким розвитком, що, зрозуміло, є набагато складнішим шляхом до прогресу як за формами, так i за технологією його забезпечення. Водночас саме цей шлях найреальніший та найбільш доцільний, такий, що «... має "приручити" глобалізацію, надати їй соціально орієнтованого характеру» [8, с. 28]. Імплементація постулатів концепції стійкого розвитку у характер перебігу глобалізаційних процесів має базуватися на збільшенні уваги до проблем соціального захисту та соціального забезпечення на всіх рівнях державного управління. До цього закликає ЮНЕСКО, пропагуючи ідеї розбудови суспільства знань та гуманізації процесу глобалізації. На конференціях, симпозіумах та інших заходах, що проводяться під егідою цієї організації, постійно наголошується на потребі гуманного розвитку всупереч поглинаючим національне різноманіття глобалізаційним процесам. 
Поширеною є думка, що причини глобальних економічних трансформацій лежать у площині сучасної масштабної інформатизації майже усіх сфер життя. Разом з тим, як зазначає А.Чугунов, у розвитку глобалізації інформаційна компонента є важливою та невизначальною [9, с. 5]. Дійсно, причини глобалізаційних зрушень варто шукати в іншому: у перенесенні ваги капіталістичної залежності з центру на периферію при збереженні за країнами-лідерами безумовного права на отримання фінансового та політичного зиску від такої експансії. Вочевидь, для країн з перехідною економікою це окреслюватиме не надто обнадійливі перспективи, а можливості виходу із замкненого кола супідрядності та залежності визначатимуться результативністю формування й використання людського капіталу на всіх рівнях економічної системи та в усіх зрізах суспільних взаємовідносин. За умов же перехідного стану економіки та зважаючи на беззаперечну потребу у форсованих змінах, прискіплива увага має бути прикута до проблем соціального захисту та соціального забезпечення, що визначається цінністю людського ресурсу та місією держави як політико-соціального інституту. Як цілком правомірно зазначається в аналітичному звіті «Система соціального захисту та соціального забезпечення в Україні. Реальний стан та перспективи реформування» [6], економічна обгрунтованість й ефективність системи соціального захисту та соціального забезпечення, їі орієнтація на потреби найбільш соціально вразливих категорій громадян входить до загальновизнаних стандартів соціально орієнтованої держави, а доступність соціальних послуг для громадян є однією з ознак високої якості життя.

Важко не погодитися з авторами [6], які звертають увагу на те, що згідно з Конституцією, яка проголосила Україну соціальною державою, пріоритет має надаватися забезпеченню соціальних та економічних прав громадян. Однак поточна економічна ситуація в Україні, незбалансованість i нерозвиненість діючої системи соціального захисту та соціального забезпечення не дають змоги повною мірою перетворити задеклароване на реальність. Непрозора система пільг та соціальних виплат, громіздка мережа державних і комунальних закладів соціального захисту та соціальних служб, неузгодженість чинного законодавства щодо соціального захисту та соціального забезпечення, у якому простежуються елементи принципово різних моделей - і радянської, і європейської - ускладнює швидке вирішення нагальних проблем у соціальній сфері. Крім того, у низці випадків запровадження пільг, соціальних та компенсаційних виплат виходить за межі «... конституційних стандартів, оскільки на рівні законів України перелік категорій одержувачів різних заходів соціального захисту значно розширено» [6, с. 6]. Це призводить до розмивання соціальної функції держави та втрати адресності соціального захисту. Втім, тут важливо брати до уваги, що засади функціонування вітчизняної системи соціального захисту та соціального забезпечення базуються не лише на законодавчих актах України, а й випливають із міжнародно-правових зобов'язань щодо соціальних прав людини. У цьому аспекті суттєвою проблемою залишається раціональність включення ратифікованих міжнародних правових актів у систему національного законодавства з урахуванням можливості практичного забезпечення їх виконання.

Висновки та перспективи подальших досліджень. Країни, що розвиваються, є основними об'єктами впливу глобалізаційного процесу в усій широті спектра його складових: соціально-економічному, політичному, соціокультурному. Майбутнє цих держав - їх благополуччя та стійкий розвиток - значною мірою залежать від розробленості дієвих механізмів опору глобалізації, насамперед тим їі впливам, що мають негативний характер та несуть руйнівні наслідки для системи соціально-економічних відносин. Сучасній Україні необхідно оперувати ефективною політикою протидії глобалізаційним загрозам, мати у своєму розпорядженні дієві засоби впорядкування процесів у різних сферах життя та активно управляти ними попри виклики глобалізації. Як було аргументовано вище, серед іншого це стосується системи соціального захисту та соціального забезпечення, нагальним пріоритетом розвитку якої $є$ збереження людського капіталу з метою його наступного результативного використання у формі доходного економічного активу. Це доводить необхідність подальших досліджень щодо призначення й ролі системи соціального захисту та соціального забезпечення, переорієнтації режиму функціонування останньої у формат сприяння збереженню людського капіталу України.

\section{Список використаної літератури:}

1. Грімнова O.A. Соціальна відповідальність у трудових відносинах: теорія, практика, регулювання ризиків : монографія / О.А. Грішнова, Г.Ю. Мішук, О.О. Олійник. - Рівне : НУВГП, 2014. - 216 с.

2. Колот А.М. Соціально-трудовий розвиток у XXI столітті: до природи глобальних змін, нових можливостей, обмежень і викликів / А.М. Колот, О.О. Герасименко // Демографія та соціальна економіка, 2019. - № 1 (35). C. $97-125$.

3. Леоненко П.М. Сучасні економічні системи : навчальний посібник / П.М. Леоненко, О.І. Черепніна. - К. : Знання, 2006. $-429 \mathrm{c}$.

4. Мельничук Д.П. Людський капітал: пріоритети модернізації суспільства у контексті поліпшення якості життя населення : монографія / Д.П. Мельничук [Електронний ресурс]. - Режим доступу : http://www.idss.org.ua/monografii/2015_Melnichuk.pdf.

5. Мельничук Д.П. Продуктивна зайнятість як передумова функціонування знань у формі капіталу / Д.П. Мельничук // Демографія та соціальна економіка. - К. : Інститут демографії та соціальних досліджень ім. М.В. Птухи НАН України, 2014. - № 2 (22). - С. 135-144. 
6. Система соціального захисту та соціального забезпечення в Україні. Реальний стан та перспективи реформування. - К. : Центр громадської експертизи, 2009. - 104 с.

7. Соціальна відповідальність : навч. посіб. / А.М. Колот, О.А. Грішнова, О.О. Герасименко та ін. ; за заг. ред. А.М. Колота. - К. : КНЕУ, 2015. - 519 с.

8. Соціалізація відносин у сфері праці в контексті стійкого розвитку : монографія / А.М. Колот, О.А. Грішнова, О.О. Герасименко та ін. ; за наук. ред. А.М. Колота. - К. : КНЕУ, 2010. - 348 с.

9. Чугунов А.В. Развитие информационного общества: теории, концепции и программы : учебное пособие / A.B. Чугунов. - СПб. : Ф-т филологии и искусств СПбГУ, 2007. - 98 с.

10. Drucker P.F. Post-Capitalist Society / P.F. Drucker. - N.Y. : Harper-Collins Publ., 1995.

\section{References:}

1. Grishnova, O.A., Mishhuk, G.Ju. and Olijnyk, O.O. (2014), Social'na vidpovidal'nist' u trudovyh vidnosynah: teorija, praktyka, reguljuvannja ryzykiv, monografija, NUVGP, Rivne, $216 \mathrm{p}$.

2. Kolot, A.M. and Gerasymenko, O.O. (2019), «Social'no-trudovyj rozvytok u HHI stolitti: do pryrody global'nyh zmin, novyh mozhlyvostej, obmezhen' i vyklykiv», Demografija ta social'na ekonomika, No. 1 (35), pp. 97-125.

3. Leonenko, P.M. and Cherepnina, O.I. (2006), Suchasni ekonomichni systemy, navch. posib., Znannja, Kyi'v, 429 p.

4. Mel'nychuk, D.P. Ljuds'kyj kapital: priorytety modernizacii' suspil'stva u konteksti polipshennja jakosti zhyttja naselennja, monografija [Online], available at: http://www.idss.org.ua/monografii/2015_Melnichuk.pdf

5. Mel'nychuk, D.P. (2014), «Produktyvna zajnjatist' jak peredumova funkcionuvannja znan' u formi kapitalu», Demografija ta social'na ekonomika, Instytut demografii' ta social'nyh doslidzhen' im. M.V. Ptuhy NAN Ukrai'ny, Kyi'v, No. 2 (22), pp. 135-144.

6. Centr gromads'koi' ekspertyzy (2009), Systema social'nogo zahystu ta social'nogo zabezpechennja v Ukrai'ni. Real'nyj stan ta perspektyvy reformuvannja, Kyi'v, 104 p.

7. Kolot, A.M., Grishnova, O.A., Gerasymenko, O.O. and al. (2015), Social'na vidpovidal'nist', navch. posib, in Kolot, A.M. (ed.), KNEU, Kyi'v, 519 p.

8. Kolot, A.M., Grishnova, O.A., Gerasymenko, O.O. and al. (2010), Socializacija vidnosyn u sferi praci v konteksti stijkogo rozvytku, monografija, in Kolot, A.M. (ed.), KNEU, K., 348 p.

9. Chugunov, A.V. (2007), Razvitie informacionnogo obshhestva: teorii, koncepcii i programmy, uchebnoe posobie, F-t filologii i iskusstv SPbGU, $\mathrm{SPb}, 98 \mathrm{p}$.

10. Drucker, P.F. (1995), Post-Capitalist Society, Harper-Collins Publ, N.Y.

Мельничук Дмитро Петрович - доктор економічних наук, доцент, професор кафедри економічної безпеки, публічного управління та адміністрування Державного університету «Житомирська політехніка».

Наукові інтереси:

- соціальне забезпечення;

- соціальна та гуманітарна політика;

- адміністративний менеджмент;

- менеджмент персоналу.

https://orcid.org/0000-0002-6550-1174.

Войналович Ірина Анатоліївна - кандидат економічних наук, доцент кафедри цифрової економіки та міжнародних економічних відносин Державного університету «Житомирська політехніка».

Наукові інтереси:

- соціальне забезпечення та соціальна відповідальність;

- людський розвиток.

https://orcid.org/ 0000-0002-6580-8049.

Леган Ірина Миколаївна - кандидат економічних наук, доцент кафедри економічної безпеки, публічного управління та адміністрування Державного університету «Житомирська політехніка».

Наукові інтереси:

- економіка праці;

- соціальне забезпечення;

- етика менеджменту в системі публічного управління.

https://orcid.org/0000-0003-2933-4971.

Тростенюк Тетяна Михайлівна - аспірантка кафедри обліку і аудиту Державного університету «Житомирська політехніка».

Наукові інтереси:

- соціальне забезпечення;

- управлінський облік у державних закладах вищої освіти;

- обліковий аспект державного фінансового забезпечення.

https://orcid.org/0000-0001-7130-7454. 